\title{
直交異方性サンドイッチ円筒殼の遮音特性*
}

\author{
長 南 征 二*1

\section{Soundproof Characteristics of Orthotropic Cylindrical Shells}

\author{
Seiji CHONAN
}

\begin{abstract}
This paper is concerned with the soundproof characteristics of infinitely long, cylindrical sand. wich shells composed of orthotropic face layers and a honeycomb core. The shell is excited by axisymmetric acoustic waves travelling within the shell. To simplify the shell governing equations it is assumed that the facings resist only bending moments and the honeycomb core resists only transverse shear forces. The sound transmission loss for the shell wall, $T L$, is derived and calculated numerically for various values of the physical parameters involved.
\end{abstract}

Key Words : Sound, Theory of Vibration, Soundproof, Orthotropic Shell

\section{1. 緒言}

繊維強化プラスチック（FRP）は重さに対する強度 の比が大きく構造部材として優れているため, 種々の 工業分野で使用されている。これらの FRPは一般に 強度に異方性を有し，したがって FRP を用いた構造 物の応答も，従来の等方材を用いた場合と種々異なる ことがわかっている.これらの問題に関連してBakerHerrmann $^{(1)}$, Greenberg-Stavsky ${ }^{(2)}$ は直交異方性を 有する積層円筒殼をとりあげ, 異方性が系の自由振動 特性にいかに影響するかを調べた。また Jain ${ }^{(3)}$ は内部 を部分的あるいは完全に流体で満たされた直交異方性 円筒款の自由振動数を求めている.さらに HerrmannBaker $^{(4)}$, Mangrum-Burns ${ }^{(5)}$ おるび Chonan ${ }^{(5)}$ は軸 対称の移動荷重を受ける無限長の直交異方性円筒殼を とりあげ, 系の応答が諸パラメータの值によりいかに 影響されるかを調べている。また Shirakawa ${ }^{(7)}$, Chonan $^{(8)}$ は, 熱衝撃, 力衝撃を受ける直交異方性円筒 殼の過渡応答を解析している。これらの論文はいずれ も殸自身の応答に注目して解析を行っているが, 排気

\footnotetext{
$*$ 昭和 63 年 3 月 12 日 東北支部第 23 期総会講演会において 講演，原稿受付 昭和 62 年 4 月 17 日.

*1 正員, 東北大学工学部（画980 仙台市荒巻字青葉).
}

用ダクト，給排水管等では殼自身の強度・応答よりも 殼から放出される騒音が問題になることがよくある。 本報はこの点にかんがみ, 直交異方性を有する表層材 とハニカムコアよりなる円筒殻の内部を軸対称の音波 が伝ぱする場合, 殼壁により音波が外部に対していか に遮音されるかを調べるものである，解析では殼に対 する運動方程式と周辺の空気に対する音響方程式より 殼壁に対する音波の透過損失 $T L$ を導き, 系内の諸パ ラメータが透過損失に及ぼす影響を調べることにす る.

\section{2. 理 論}

図 1 は空気中におかれれた無限長のサンドイッチ円筒 殼の一部を示したものである，殼は，直交異方性を有 する厚さ $h_{f} / 2$ の内外層と厚さ $h_{c}$ のハニカムコアより なっている. 殼の内部には軸対称の音圧 $p(x, t)$ が $x$ の正方向に伝ぱしており，殼壁はその音圧により加振 されている：この場合殼の応答も軸対称となり，殼の 周方向変位は零となる. 以下, 殼の $x$ 方向変位を $u, r$ 方向変位を $w, r x$ 面内の回転角を $\psi$ とする. また表 層の諸量については $f$, コアについてはcの下添字を つけ各々を区別することにする。一般にサンドイッチ 殼の表層材はコアに対して十分薄いが，この場合表層 
のせん断抵抗は曲げ抵抗に比して十分小さい，また八 ニカムコアについて言えば曲げ抵抗はせん断抵抗に比 して十分小さい。このことを考慮し，以下では表層材 については曲げ抵抗，コアについてはせん断抵抗のみ を考慮し殼の方程式を組立てる。なお，殼の内部には 温度変化等により軸方向に面内力が作用することが多 いため,ここでも式中に軸方向面内力 $P_{x}$ の影響を含 めることにする。

厚肉殼理論を適用し, 本題の殻に対して運動方程式 を組立てると ${ }^{(1)}$

$$
\begin{aligned}
& {\left[\left(E_{x}+P_{x}\right) \frac{\partial^{2}}{\partial x^{2}}-m_{\rho} \frac{\partial^{2}}{\partial t^{2}}\right] u+\left[\frac{E_{\nu}}{R_{0}} \frac{\partial}{\partial x}\right] w} \\
& \quad+\left[-\frac{D_{x}}{R_{0}} \frac{\partial^{2}}{\partial x^{2}}+\frac{I_{\rho}}{R_{0}} \frac{\partial^{2}}{\partial t^{2}}\right] \psi=0 \cdots \cdots \cdots \cdots(1) \\
& {\left[\frac{E_{\nu}}{R_{0}} \frac{\partial}{\partial x}\right] u+\left[-\left(G_{x}+P_{x}\right) \frac{\partial^{2}}{\partial x^{2}}+\frac{1}{R_{0}^{2}}\left(E_{0}+\frac{D_{0}}{R_{0}^{2}}\right)\right.} \\
& \left.\quad+m_{\rho} \frac{\partial^{2}}{\partial t^{2}}\right] w+\left[G_{x} \frac{\partial}{\partial x}\right] \psi=\left[1-\frac{h_{f}+h_{c}}{2 R_{0}}\right] p(x, t)
\end{aligned}
$$

$$
\begin{aligned}
& {\left[\frac{D_{x}}{R_{0}} \frac{\partial^{2}}{\partial x^{2}}-\frac{I_{\rho}}{R_{0}} \frac{\partial^{2}}{\partial t^{2}}\right] u+\left[-G_{x} \frac{\partial}{\partial x}\right] w} \\
& \quad+\left[-D_{x} \frac{\partial^{2}}{\partial x^{2}}+G_{x}+I_{\rho} \frac{\partial^{2}}{\partial t^{2}}\right] \psi=0 \quad \cdots
\end{aligned}
$$

上式に扔いて

$$
\begin{aligned}
& E_{x}=E_{x f} h_{f}, \quad E_{\theta}=E_{\theta f} h_{f}, \quad E_{\nu}=E_{\nu f} h_{f} \\
& G_{x}=x_{c} G_{x} h_{c}, \quad D_{x}=E_{x f} I_{f}, \quad D_{\theta}=E_{\theta f} I_{f} \\
& I_{f}=\frac{h_{f} h_{c}^{2}}{4}+\frac{h_{c} h_{f}^{2}}{4}+\frac{h_{f}^{3}}{12} \\
& I_{\rho}=\rho_{f} I_{f}+\rho_{c} \frac{h_{c}^{3}}{12}, \quad m_{\rho}=\rho_{f} h_{f}+\rho_{c} h_{c}
\end{aligned}
$$

ここに $E_{x f}, E_{\theta f}$ および $E_{\nu f}$ は表層材の弾性定数, $G_{x c}$ は八ニカムコアの横弾性定数, $x_{c}\left(=\pi^{2} / 12\right)$ はせん断 修正係数, $\rho$ は質量密度, $R_{0}$ は殼の平均半径を表す。

さて，構造物の遮音特性を表すパラメータとして一 般に音の透過損失係数 $T L$ が使用されるが, 直交異方 性円筒殼については未だ TLの一般式は得られてい ない. 以下式 $(1) \sim(3)$ を用い $T L$ を導いてみよう.

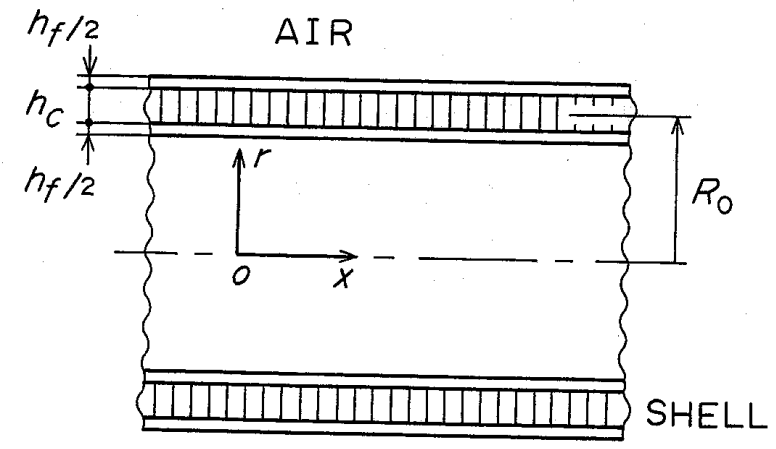

図 1 ハニカムコアを有する直交異方性円筒殼
殼内を伝ぱしている音波は一般に次のように表され る.

$$
p(x, t)=P e^{-i \xi x x} e^{i \omega t}
$$

上式において $P$ は音圧振幅， $\xi_{x}$ は波の波数， $\omega$ は角 振動数を表す. $\xi_{x}$ と $\omega$ は音速 $c_{x}$ を介して以下のよう に結びついている。

$\xi_{x}=\omega / c_{x}$

殸は式 ( 4 )の音波により加振されるが, この場合殼の 変位および回転角は次のように表される。

$\{u, w, \phi\}=\{U, W, \Psi\} e^{-i \xi x x} e^{i \omega t}$

式 (6)を式 (1)〜 (3)に代入し整理すると

$\left[a_{i j}\right][W, i U, i \Psi]^{T}=\left[0, b_{2}, 0\right]^{T}$

上式において

$$
\begin{aligned}
a_{11} & =\frac{E_{\nu f}}{E_{x f}} \frac{h_{f}}{R_{0}} \frac{\omega}{c_{x}} \\
a_{12} & =\left(h_{f}+\frac{\rho_{c}}{\rho_{f}} h_{c}\right) \frac{\omega^{2}}{c_{l f}^{2}}-\left(h_{f}+\frac{P_{x}}{E_{x f}}\right) \frac{\omega^{2}}{c_{l f}^{2}} \\
a_{13} & =-\frac{1}{R_{0}}\left(\frac{h_{f} h_{c}^{2}}{4}+\frac{h_{c} h_{f}^{2}}{4}+\frac{h_{f}^{3}}{12}+\frac{\rho_{c}}{\rho_{f}} \frac{h_{c}^{3}}{12}\right) \frac{\omega^{2}}{c_{l f}^{2}} \\
& +\frac{1}{R_{0}}\left(\frac{h_{f} h_{c}^{2}}{4}+\frac{h_{c} h_{f}^{2}}{4}+\frac{h_{f}^{3}}{12}\right) \frac{\omega^{2}}{c_{x}^{2}} \\
a_{21} & =\left(h_{f}+\frac{\rho_{c}}{\rho_{f}} h_{c}\right) \frac{\omega^{2}}{c_{l f}^{2}} \\
& -\frac{\rho_{c}}{\rho_{f}} \frac{C_{s c}^{2}}{c_{l f}^{2}}\left(h_{c}+\frac{P_{x}}{x_{c} G_{x c}}\right) \frac{\omega^{2}}{c_{x}^{2}} \\
& -\frac{E_{o f}}{E_{x f}} \frac{1}{R_{0}^{2}}\left[h_{f}+\frac{1}{R_{0}^{2}}\left(\frac{h_{f} h_{c}^{2}}{4}+\frac{h_{c} h_{f}^{2}}{4}+\frac{h_{f}^{3}}{12}\right)\right] \\
a_{22} & =a_{11} \\
a_{23} & =h_{c} \frac{\rho_{c}}{\rho_{f}} \frac{C_{s c}^{2}}{c_{l f}^{2}} \frac{\omega}{c_{x}} \\
a_{31} & =a_{23,}, a_{32}=a_{13} \\
a_{33} & =\left(\frac{h_{f} h_{c}^{2}}{4}+\frac{h_{c} h_{f}^{2}}{4}+\frac{h_{f}^{3}}{12}+\frac{\rho_{c}}{\rho_{f}} \frac{h_{c}^{3}}{12}\right) \frac{\omega^{2}}{c_{l f}^{2}} \\
& -\left(\frac{h_{f} h_{c}^{2}}{4}+\frac{h_{c} h_{f}^{2}}{4}+\frac{h_{f}^{3}}{12}\right) \frac{\omega^{2}}{c_{x}^{2}}-\frac{\rho_{c}}{\rho_{f}} \frac{c_{s c}^{2}}{c_{l f}^{2}} h_{c} \\
b_{2}= & -\frac{1}{c_{l f}^{2}} \frac{1}{\rho_{f}}\left(1-\frac{h_{f}+h_{c}}{2 R_{0}}\right) P \\
c_{l f}^{2} & =E_{x f} / \rho_{f}, \quad c_{s c}^{2}=x_{c} G_{c} / \rho_{c}
\end{aligned}
$$

上式に扔いて $c_{\text {lf }}$ は表層内の $x$ 方向䋛波速度, $c_{s c}$ は コア内の Rayleigh 波速度を表す。式(7)より，W，U， $\Psi$ が決定される，例えば，殼の半径方向変位振幅 $W$ は

$$
W=b_{2}\left(a_{13} a_{32}-a_{12} a_{33}\right) / \operatorname{det}\left(a_{i j}\right)
$$

次に殼の周国に存在する空気内の音の伝ぱを考え る.殼が振動すると殼に接している空気が加振され音 波が発生する．ここでは殼が軸対称振動している場合 を考えているが，この場合周囲の空気内の音波の分布 も軸対称となる．いま空気内の音圧を $p_{0}$ とすると, $p_{0}$ は次の Helmholtz の音響方程式を満足する。 


$$
\left(\frac{\partial^{2}}{\partial r^{2}}+\frac{1}{r} \frac{\partial}{\partial r}+\frac{\partial^{2}}{\partial x^{2}}\right) p_{0}=\frac{1}{c_{0}^{2}} \frac{\partial^{2} p_{0}}{\partial t^{2}}
$$

$こ こ に$

$$
c_{0}^{2}=K_{0} / \rho_{0}
$$

であり， $K_{0}$ は空気の体積弾性率, $\rho_{0}$ は密度, $c_{0}$ は音速 を表す。殼の応答式, 式(6)，にならい $p_{0}$ を次のよう に置く。

$$
p_{0}(r, x, t)=A(r) e^{-i \xi x x} e^{i \omega t}
$$

上式を式(9)に代入し $A$ を求めると

$$
p_{0}=P_{0} H_{0}^{(2)}\left(\xi_{r} r\right) e^{-i \xi_{x} x} e^{i \omega t}
$$

ここに

$$
\xi_{r}^{2}=\xi_{0}^{2}-\xi_{x}^{2}=\left(\omega / c_{0}\right)^{2}-\xi_{x}^{2}
$$

上式において $H_{0}^{(2)}(\cdot)$ は第 2 種 Hankel 関数， $\xi_{0}$ は波 の伝ぱ方向の波数, $P_{0}$ は音王振幅を表す. $P_{0}$ は殼と空 気の境界条件を用いて決定される、殼の表面では空気 と殼の半径方向速度が連続であることより

$$
\begin{aligned}
& r=R_{0}+\frac{h_{f}+h_{c}}{2} \text { において } \\
& \frac{\partial w}{\partial t}=u_{r} \ldots \ldots \ldots \ldots \ldots \ldots \ldots \ldots \ldots \ldots \ldots \ldots
\end{aligned}
$$

上式において $u_{r}$ は空気の半径方向速度であり次式で 与えられる。

$$
\frac{\partial u_{r}}{\partial t}=-\frac{\partial}{\partial r}\left(\frac{p_{0}}{\rho_{0}}\right)
$$

式(11)，(14)より

$$
u_{r}=\frac{i P_{0}}{\rho_{0} \omega} \frac{\partial}{\partial r} H_{0}^{(2)}\left(\xi_{r} r\right) e^{-i \xi x x} e^{i \omega t}
$$

さて, 殼の外径寸法はいま考えている空間全体から みた場合十分に小さいと考えられる，rが小のとき Hankel 関数は次のように表される.

$$
H_{0}^{(2)}\left(\xi_{r} r\right)=1-i(2 / \pi)\left[\ln \left(\xi_{r} r\right)-0.1159\right]
$$

式(15)，(16)を式(13)に代入すると音圧振幅 $P_{0}$ が殼 外壁の変位振幅 $W$ を用いて表される. 得られた結果 をさらに式(11)に代入すると

$$
\begin{aligned}
p_{0} & =\frac{1}{2} i \omega^{2} \rho_{0} \pi\left(R_{0}+\frac{h_{f}+h_{c}}{2}\right) W \\
& \times H_{0}^{(2)}\left(\xi_{r} r\right) e^{-i \xi x x} e^{i \omega t} \ldots \ldots \ldots . . .
\end{aligned}
$$

さて, 排気ダクト, 給排水管等と我々の耳の位置関 係を考えると，両者は一般に十分離れていることが多 い.この点を考慮し以下では殻から十分離れた位置で の音の特性につき調べていくことにする.

rが大のとき Hankel 関数は次のように表される.

$$
H_{0}^{(2)}\left(\xi_{r} r\right)=\left[\frac{2}{\pi \xi_{r} r}\right]^{1 / 2} e^{-i(\xi r r-\pi / 4)}
$$

音圧 $p_{0}$ 点の音の強さを $I_{0}$ とすると

$$
I_{0}=\left|p_{0}\right|^{2} / 2 \rho_{0} c_{0}
$$

式(18)を式(17)に代入し, 得られた式をさらに式(19)
に代入すると

$$
I_{0}=\frac{\omega^{4} \rho_{0} \pi W^{2}}{4 c_{0} \xi_{r} r}\left(R_{0}+\frac{h_{f}+h_{c}}{2}\right)^{2}
$$

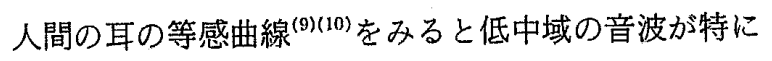
騒音として我々に聞こえやすいことがわかる．低中域 の波に対しては殼内を伝ぱする波の波数 $\xi_{x}$ は一般に 十分に小さい.したがって式(12)より

$$
\xi_{r} \doteqdot \xi_{0}=\omega / c_{0}
$$

式(21)を用いると式(20)はさらに次のように変形され 万.

$$
I_{0}=\frac{\omega^{3} \rho_{0} \pi W^{2}}{4 r}\left(R_{0}+\frac{h_{f}+h_{c}}{2}\right)^{2}
$$

単位長さ当たり殼より放出される音響エネルギーを $S$ とすると, $S$ は次式で与えられる.

$$
\begin{aligned}
S & =2 \pi r I_{0} \\
& =\frac{1}{2} \rho_{0} \omega^{3} \pi^{2}\left(R_{0}+\frac{h_{f}+h_{c}}{2}\right)^{2} W^{2}
\end{aligned}
$$

$S$ を殼の外表面積でわると，殼から十分に離れた位置 から見た場合の殼壁表面における透過波の強さ $I_{t}$ が 得られる。すなわち

$$
\begin{aligned}
I_{t} & =S / 2 \pi\left(R_{0}+\frac{h_{f}+h_{c}}{2}\right) \\
& =\frac{1}{4} \rho_{0} \omega^{3} \pi\left(R_{0}+\frac{h_{f}+h_{c}}{2}\right) W^{2}
\end{aligned}
$$

次に殼内の音響エネルギーを考える，殼の内部と外部 では温度等のちがいで空気の物性は厳密には異なる が, 両者の差は小さいと考えられる.したがって $c_{x}$ $C_{0}$ これより, 殼内部の音の強さを $I_{i}$ とすると

$$
I_{i}=P^{2} / 2 \rho_{0} c_{0}
$$

したがって，殼壁に対する音響エネルギーの透過損失 を $T L$ とすると

$$
\begin{aligned}
T L & =10 \log _{10}\left(I_{i} / I_{i}\right) \\
& =10 \log _{10} \frac{2}{\rho_{0}^{2} c_{0} \omega^{3} \pi\left(R_{0}+\frac{h_{f}+h_{c}}{2}\right)(W / P)^{2}}
\end{aligned}
$$

透過損失 $T L$ が大きい程殼壁からの音響エネルギー の漏れが少ないことになる、したがって殼の遮音性は 優れている，以下，表層が一方向強化の FRP，コアが アルミニウムのハニカムである場合をとりあげ，諸パ ラメータの変化による透過損失を調べることにする.

\section{3. 数 值 結 果}

数値計算で使用する物理定数を以下に示す.

$$
\begin{aligned}
\text { (1) } & \text { 空気 } \\
c_{0}= & 340 \mathrm{~m} / \mathrm{s} \\
\rho_{0}= & 0.0012 \times 10^{3} \mathrm{~kg} / \mathrm{m}^{3}
\end{aligned}
$$

（2）FRP 表層 


$$
\begin{aligned}
& \rho_{f}=1.7 \times 10^{3} \mathrm{~kg} / \mathrm{m}^{3} \\
& E_{x f}=(0.85 \sim 3.4) \times 10^{10} \mathrm{~N} / \mathrm{m}^{2} \\
& E_{\theta f}=(0.85 \sim 3.4) \times 10^{10} \mathrm{~N} / \mathrm{m}^{2} \\
& E_{\nu f}=(0.17 \sim 0.85) \times 10^{10} \mathrm{~N} / \mathrm{m}^{2}
\end{aligned}
$$

(3) アルミニウムハニカムコア

$$
\begin{aligned}
& \rho_{c}=0.13 \times 10^{3} \mathrm{~kg} / \mathrm{m}^{3} \\
& G_{x c}=(0.35 \sim 1.07) \times 10^{9} \mathrm{~N} / \mathrm{m}^{2}
\end{aligned}
$$

図 2 は表層材の強化方向を, 周方向（曲線 1)におい た場合と，軸方向（曲線 2) におろいた場合の透過損失の 值を, 人間の可聴域 $(0 \sim 20 \mathrm{kHz})$ について示したもの である.いずれも $T L$ は振動数が零のとき無限大の值 をとり, 振動数の増加とともに最小值に至った後再び 増大していく. TL が $2 \mathrm{kHz}$ 近傍で最小值をとり音が 殼壁を透過しやすくなる現象はコインシデンス効果と 呼ばれているが,これは殼内を伝ぱしている音の速度 が殼の曲げ自由波の速度に一致し，一種の共振が殼壁 に生じるためである. 以下，TLが最小となる振動数 をコインシデンス振動数と呼ぶ.一般に音に対する人 間の耳の感度（聞こえやすさ）は音の振動数の増加と ともに良好となり，3〜 $4 \mathrm{kHz}$ で最大となった後再び 減少していくことがわかっているが(9)(10),このことを 考えると $T L$ は $4 \mathrm{kHz}$ でできるだけ高いほうが良 いことが言える．図をみると軸方向に強化した場合は 周方向に強化した場合に比しコインシデンスによる $T L の$ 落ち込みが多少大きいものの, $2 \mathrm{kHz}$ 以上では 逆に TLの值が大きくなり, 可聴域の全域を考えた場

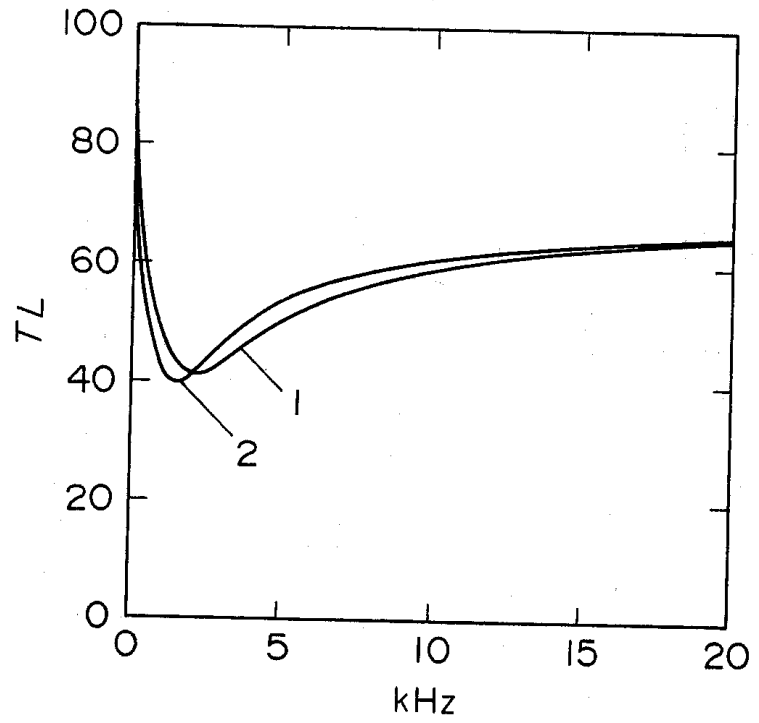

$R_{0}=0.15 \mathrm{~m}, h_{f}=0.001 \mathrm{~m}, h_{c}=0.01 \mathrm{~m}$ $E_{\nu f}=5.1 \times 10^{9} \mathrm{~N} / \mathrm{m}^{2}, \rho_{f}=1.7 \times 10^{3} \mathrm{~kg} / \mathrm{m}^{3}$ $G_{x c}=8.3 \times 10^{8} \mathrm{~N} / \mathrm{m}^{2}, \rho_{c}=0.13 \times 10^{3} \mathrm{~kg} / \mathrm{m}^{3}, P_{x}=0 \mathrm{~N} / \mathrm{m}$ 曲線 $1 E_{x f}=1.7 \times 10^{10} \mathrm{~N} / \mathrm{m}^{2}, E_{\theta f}=3.4 \times 10^{10} \mathrm{~N} / \mathrm{m}^{2}$ 曲線 $2 E_{o s}=1.7 \times 10^{10} \mathrm{~N} / \mathrm{m}^{2}, E_{x f}=3.4 \times 10^{10} \mathrm{~N} / \mathrm{m}^{2}$

図 2 表層材の強化方向のちがいによる $T L$ の変化
合強化方向を軸方向に合わせたほうが遮音の点からは 良いことが言える。

図 3 は, 軸方向の弾性定数 $E_{x f}$ の值を $1.7 \times 10^{10} \mathrm{~N} /$ $\mathrm{m}^{2}$ と固定し, 周方向の弾性定数 $E_{\text {of }}$ を変化させた場 合の透過損失の值の変化を示す． $E_{\theta f}$ の変化は低振動 数域の $T L に$ 対してのみ影響を与え，中高振動数域の $T L に は ⿰^{\prime}$ に影響しないことがわかる。また $E_{\theta f}$ が $E_{x f}$ の值に比して小さくなるに従い,コインシデンス による TLの落ち込みがより顕著となっている。これ より $E_{\theta f}$ の值が $E_{x f}$ に対して極端に小さくなること は遮音の点からみて避けなければならないことがわか る. 図 4 は $E_{o f}$ を $1.7 \times 10^{10} \mathrm{~N} / \mathrm{m}^{2}$ と固定し, 逆に $E_{x f}$ を変化させた場合の $T L$ の変化を示す.この場合は振 動数の全域で $T L$ の値が影響を受け変化している.以

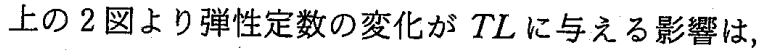
殼の軸方向と周方向で傾向を異にすることが一般に言 える。

図 5 は $E_{\nu f}$ を変えた場合の透過損失の変化を示す。 $E_{\nu f}$ は材料内の縦ひずみに付随して生ずる横ひずみの 大きさに関係する弾性定数で, 等方弾性体の場合 $E_{\nu f} / E_{x f}$ あるいは $E_{\nu f} / E_{\theta f}$ の值がポアソン比 $レ$ に相当

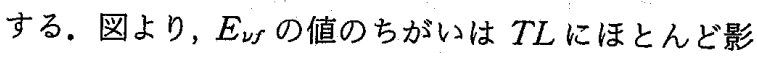
響を与えないことがわかる。

図 6 は八ニカムコアのせん断こわさ $G_{x c}$ を変化さ

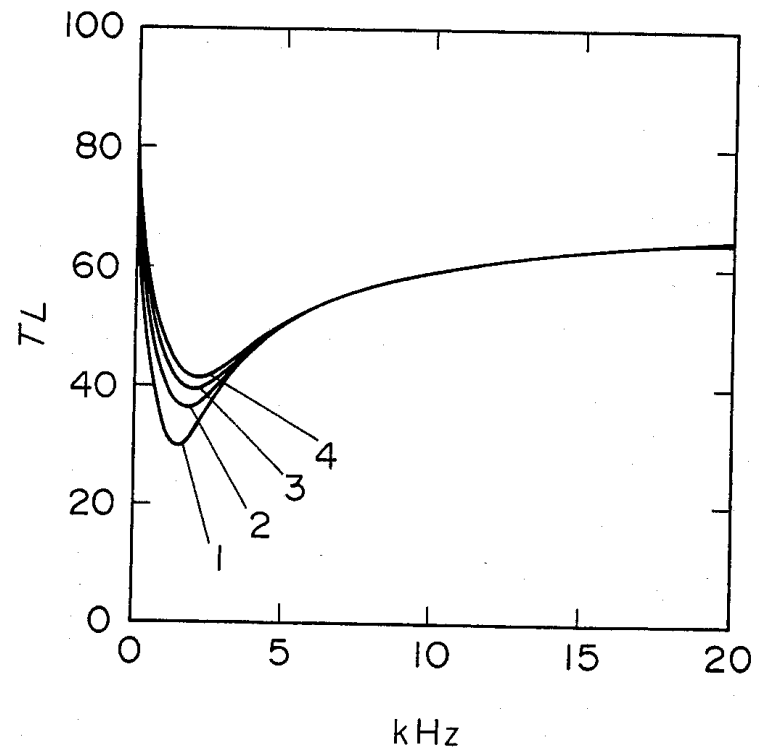

$R_{0}=0.15 \mathrm{~m}, h_{f}=0.001 \mathrm{~m}, h_{c}=0.01 \mathrm{~m}$ $E_{x f}=1.7 \times 10^{10} \mathrm{~N} / \mathrm{m}^{2}, E_{u f}=5.1 \times 10^{9} \mathrm{~N} / \mathrm{m}^{2}$ $\rho_{f}=1.7 \times 10^{3} \mathrm{~kg} / \mathrm{m}^{3}, G_{x \mathrm{c}}=8.3 \times 10^{8} \mathrm{~N} / \mathrm{m}^{2}$ $\rho_{c}=0.13 \times 10^{3} \mathrm{~kg} / \mathrm{m}^{3}, P_{x}=0 \mathrm{~N} / \mathrm{m}$ 曲線 $1 E_{\theta f} / E_{x f}=0.5$, 曲線 $2 \quad E_{\theta f} / E_{x f}=1.0$ 曲線 $3 E_{\theta f} / E_{x f}=1.5$, 曲線 $4 E_{o f} / E_{x f}=2.0$

図 $3 E_{\theta_{f}}$ の変化による $T L$ の変化 
せた場合の透過損失の変化を示す.コインシデンス効 果による $T L の$ 落ち込みは $G_{x c}$ の值でほとんど変化 がないが，中高域の音に対しては $G_{x c}$ が増大すると $T L$ が一様に大きくなり全体として殻の遮音特性が改 善されることがわかる。

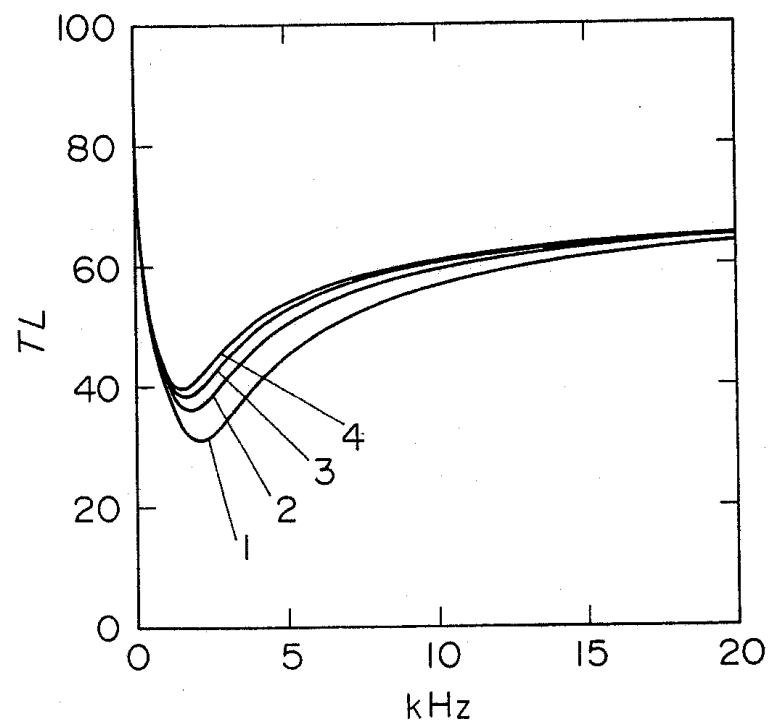

$R_{0}=0.15 \mathrm{~m}, h_{s}=0.001 \mathrm{~m}, h_{c}=0.01 \mathrm{~m}$ $E_{\theta f}=1.7 \times 10^{10} \mathrm{~N} / \mathrm{m}^{2}, E_{\nu f}=5.1 \times 10^{9} \mathrm{~N} / \mathrm{m}^{2}$ $\rho_{f}=1.7 \times 10^{3} \mathrm{~kg} / \mathrm{m}^{3}, G_{x c}=8.3 \times 10^{8} \mathrm{~N} / \mathrm{m}^{2}$ $\rho_{c}=0.13 \times 10^{3} \mathrm{~kg} / \mathrm{m}^{3}, P_{x}=0 \mathrm{~N} / \mathrm{m}$ 曲線 $1 \quad E_{x f} / E_{o f}=0.5$, 曲線 $2 \quad E_{x f} / E_{\theta f}=1.0$ 曲線 $3 \quad E_{x f} / E_{a f}=1.5$, 曲線 $4 \quad E_{x f} / E_{\theta f}=2.0$

図 $4 E_{x f}$ の変化による $T L$ の変化

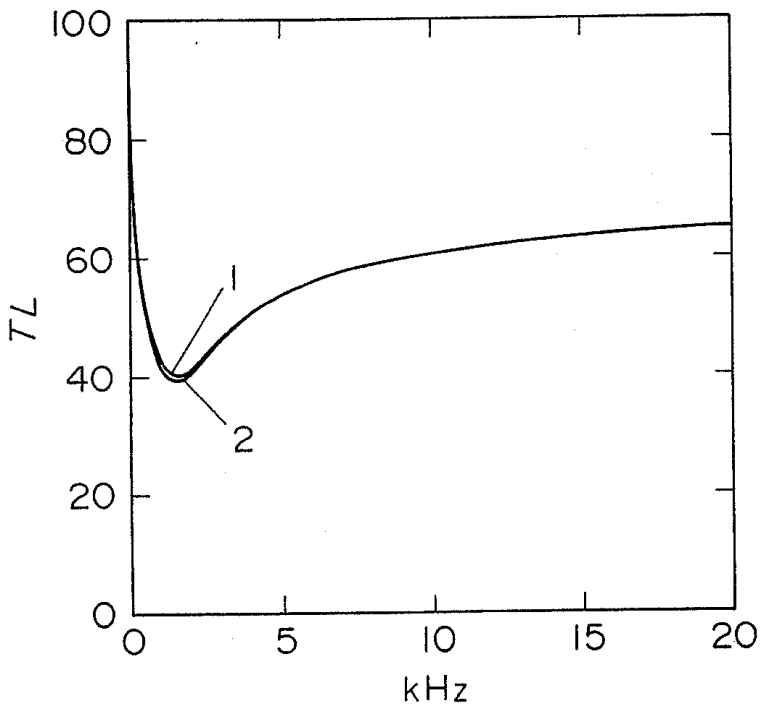

$R_{0}=0.15 \mathrm{~m}, h_{f}=0.001 \mathrm{~m}, h_{c}=0.01 \mathrm{~m}$ $E_{o r}=1.7 \times 10^{10} \mathrm{~N} / \mathrm{m}^{2}, E_{x s}=3.4 \times 10^{10} \mathrm{~N} / \mathrm{m}^{2}$ $\rho_{s}=1.7 \times 10^{3} \mathrm{~kg} / \mathrm{m}^{3}, G_{x c}=8.3 \times 10^{8} \mathrm{~N} / \mathrm{m}^{2}$ $\rho_{c}=0.13 \times 10^{3} \mathrm{~kg} / \mathrm{m}^{3}, P_{x}=0 \mathrm{~N} / \mathrm{m}$

曲線 $1 E_{\nu f}=1.7 \times 10^{9} \mathrm{~N} / \mathrm{m}^{2}$, 曲線 $2 E_{\nu f}=8.5 \times 10^{9} \mathrm{~N} / \mathrm{m}^{2}$ 図 $5 \quad E_{\nu f}$ の変化による $T L$ の変化
図 7 は殼の平均半径 $R_{0}$ を変えた場合の透過損失の 変化を示したものである. 図より殼の平均半径が大き くなるにつれて透過損失は全振動数域で減少し, 特に コインシデンス域での減少が顕著となることがわか る.ダクト, 給排水管等の寸法は一般に排気量, 給排水 量により規定されるが，それらの直径は音響学上から 言えば可能な限り小さくすべきであることが，この図 からわかる.

図 8 はコアの厚さを $h_{c}=0.01 \mathrm{~m}$ と固定し, 表層の 厚さ $h_{f}$ を変えた場合の透過損失の変化を示したもの である.表層の厚さの増加は中高振動数域の $T L$ に対 してはあまり影響を与えないが，コインシデンス効果 でTLが減少する低振動数域での值を著しく増大さ せることがわかる。

図 9 は表層の厚さを $h_{f}=0.001 \mathrm{~m}$ と固定し, コアの 厚さ $h_{c}$ を変えた場合の透過損失の変化を示したもの である.コアの厚さの増加とともに TLは全振動数域 で増大し，またコインシデンス振動数は $2 \mathrm{kHz}$ から 1 $\mathrm{kHz}$ へと低下している.この, 1 $2 \mathrm{kHz}$ の音域では 人間の耳の感度が振動数の低下とともに鈍くなる(9)(10) ことを考えると，TLの増加と同時にコインシデンス 振動数が低くなることは騒音対策のうえからみて非常 に好ましいことと言える。

図 10 は殼の厚さ $h_{s}+h_{c}$ を $0.011 \mathrm{~m}$ と固定し, 内部 での $h_{f}$ と $h_{c}$ の厚さ配分を変えた場合の透過損失の

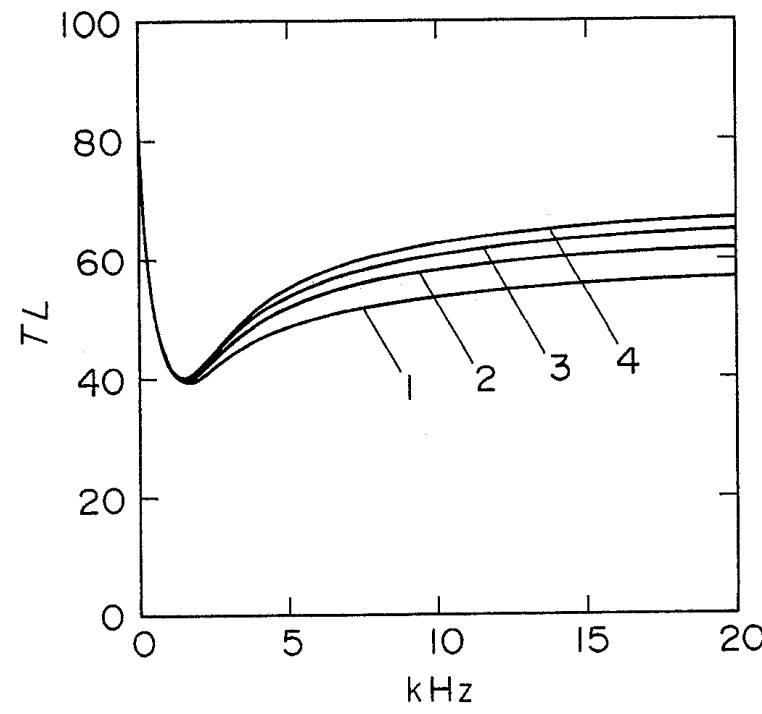

$R_{0}=0.15 \mathrm{~m}, h_{f}=0.001 \mathrm{~m}, h_{c}=0.01 \mathrm{~m}$ $E_{v f}=1.7 \times 10^{10} \mathrm{~N} / \mathrm{m}^{2}, E_{x f}=3.4 \times 10^{10} \mathrm{~N} / \mathrm{m}^{2}$ $E_{\nu f}=5.1 \times 10^{9} \mathrm{~N} / \mathrm{m}^{2}, \rho_{f}=1.7 \times 10^{3} \mathrm{~kg} / \mathrm{m}^{3}$ $\rho_{c}=0.13 \times 10^{3} \mathrm{~kg} / \mathrm{m}^{3}, P_{x}=0 \mathrm{~N} / \mathrm{m}$

曲線 $1 G_{x c}=3.5 \times 10^{8} \mathrm{~N} / \mathrm{m}^{2}$, 曲線 $2 G_{x c}=5.9 \times 10^{8} \mathrm{~N} / \mathrm{m}^{2}$ 曲線 $3 G_{x c}=8.3 \times 10^{8} \mathrm{~N} / \mathrm{m}^{2}$, 曲線 $4 G_{x c}=10.7 \times 10^{8} \mathrm{~N} / \mathrm{m}^{2}$

図 $6 G_{x c}$ の変化による $T L$ の変化 
変化を示したものである．表層が厚くなるに従いコイ ンシデンスによる TLの落ち込みが改善されている. 一方, 中高振動数域では $T L$ 值が小さくなっている が減少の度合はコインシデンス域での増加の度合に比

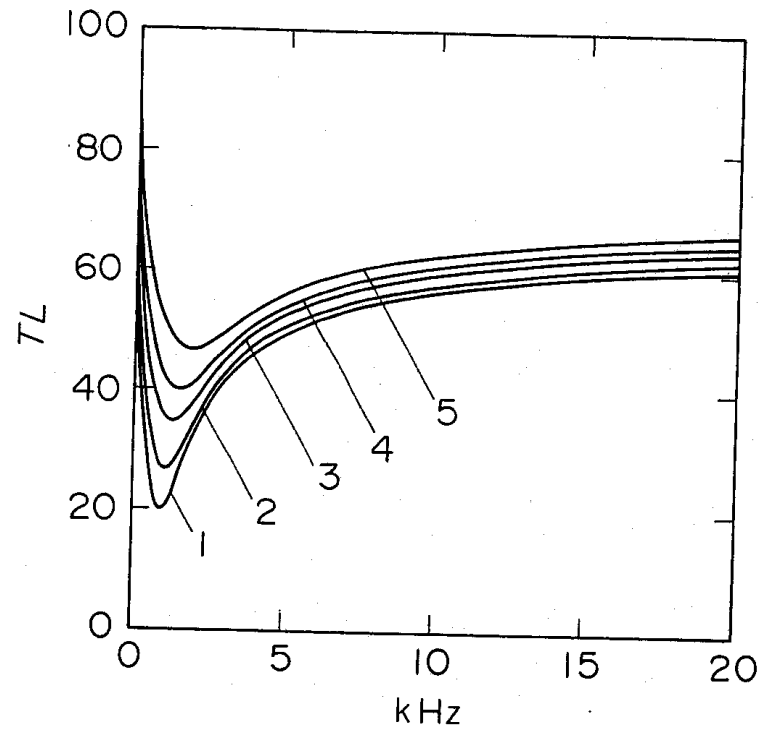

$h_{f}=0.001 \mathrm{~m}, h_{c}=0.01 \mathrm{~m}, E_{u f}=1.7 \times 10^{10} \mathrm{~N} / \mathrm{m}^{2}$

$E_{x f}=3.4 \times 10^{10} \mathrm{~N} / \mathrm{m}^{2}, E_{\nu f}=5.1 \times 10^{9} \mathrm{~N} / \mathrm{m}^{2}$

$G_{x c}=8.3 \times 10^{8} \mathrm{~N} / \mathrm{m}^{2}, \rho_{f}=1.7 \times 10^{3} \mathrm{~kg} / \mathrm{m}^{3}$

$\rho_{c}=0.13 \times 10^{3} \mathrm{~kg} / \mathrm{m}^{3}, P_{x}=0 \mathrm{~N} / \mathrm{m}$

曲線 $1 R_{0}=0.40 \mathrm{~m}$, 曲線 $2 R_{0}=0.30 \mathrm{~m}$, 曲線 $3 R_{0}=0.20 \mathrm{~m}$

曲線 $4 R_{0}=0.15 \mathrm{~m}$, 曲線 $5 \quad R_{0}=0.10 \mathrm{~m}$

図 $7 \quad R_{0}$ の変化による $T L$ の変化

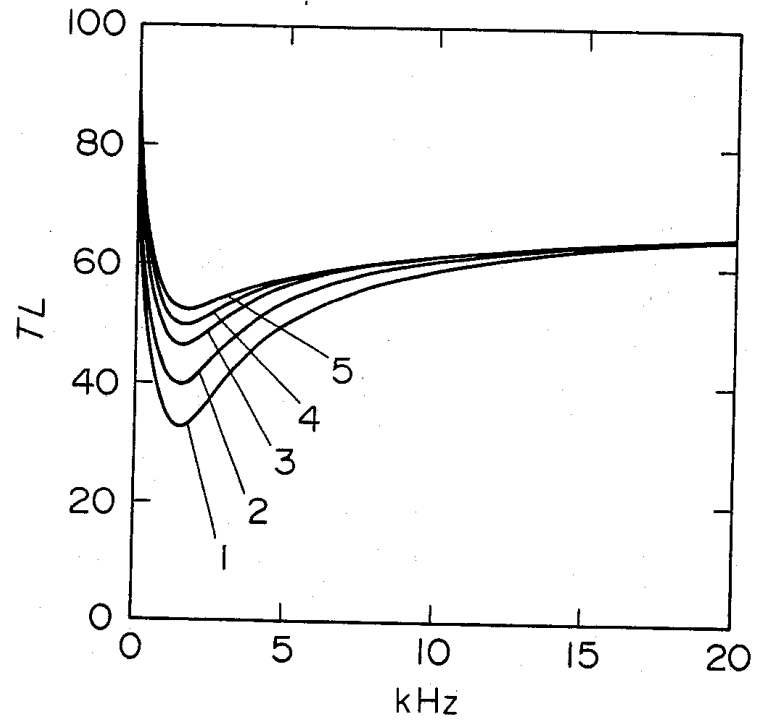

$R_{0}=0.15 \mathrm{~m}, h_{c}=0.01 \mathrm{~m}, E_{\theta f}=1.7 \times 10^{10} \mathrm{~N} / \mathrm{m}^{2}$

$E_{x f}=3.4 \times 10^{10} \mathrm{~N} / \mathrm{m}^{2}, E_{\nu f}=5.1 \times 10^{9} \mathrm{~N} / \mathrm{m}^{2}$

$G_{x c}=8.3 \times 10^{8} \mathrm{~N} / \mathrm{m}^{2}, \rho_{f}=1.7 \times 10^{3} \mathrm{~kg} / \mathrm{m}^{3}$

$\rho_{c}=0.13 \times 10^{3} \mathrm{~kg} / \mathrm{m}^{3}, P_{x}=0 \mathrm{~N} / \mathrm{m}$

曲線 $1 h_{f}=0.0005 \mathrm{~m}$, 曲線 $2 h_{f}=0.0010 \mathrm{~m}$

曲線 $3 h_{f}=0.0020 \mathrm{~m}$, 曲線 $4 h_{f}=0.0030 \mathrm{~m}$

曲線 $5 h_{s}=0.0040 \mathrm{~m}$

図 $8 h_{f}$ の変化による $T L$ 変化
して十分小さい．以上の二点を考えると殼の厚さが固 定さ机ている場合，表層を厚くするほうが壳の遮音特 性が改善されると言える。

図 11 は殼内の軸方向面内力 $P_{x}$ を変えた場合の透 過損失の変化を示したものである. $P_{x}= \pm 5 \times 10^{4} \mathrm{~N} / \mathrm{m}$ は $h_{f}=0.001 \mathrm{~m}$ の表層に対して,ひずみ $\pm 1.5 \times 10^{-3}$ に相当する. 図より TLは面内力によってほとんど変 化せず，その影響は本解析でとりあげている殼の音響 特性に対しては無視できる程度であることがわかる。

\section{4. 結言}

直交異方性を有する表層材と八ニカムコアよりなる 円筒殼の内部を軸対称の音波が伝ぱする場合につき， 殼壁に対する透過損失 $T L$ を求め, 数値計算を行いそ の特性を調べた，得られた結果を要約すると次のよう になる。

（1）一方向強化材を表層材に用いるときは，強化 方向を殼の軸方向に合わせたほうが良い遮音特性が得 られる。

（2）表層の周方向弾性定数 $E_{\theta f}$ の増加は低振動 数域の透過損失の值を増大させる.

（3）表層の軸方向弾性定数 $E_{x f}$ の増加は全振動 数域で透過損失の值を増大させる.

（4）八ニカムコアのせん断こわき $G_{x c}$ の増加は, 中高振動数域で透過損失の值を増大させる.

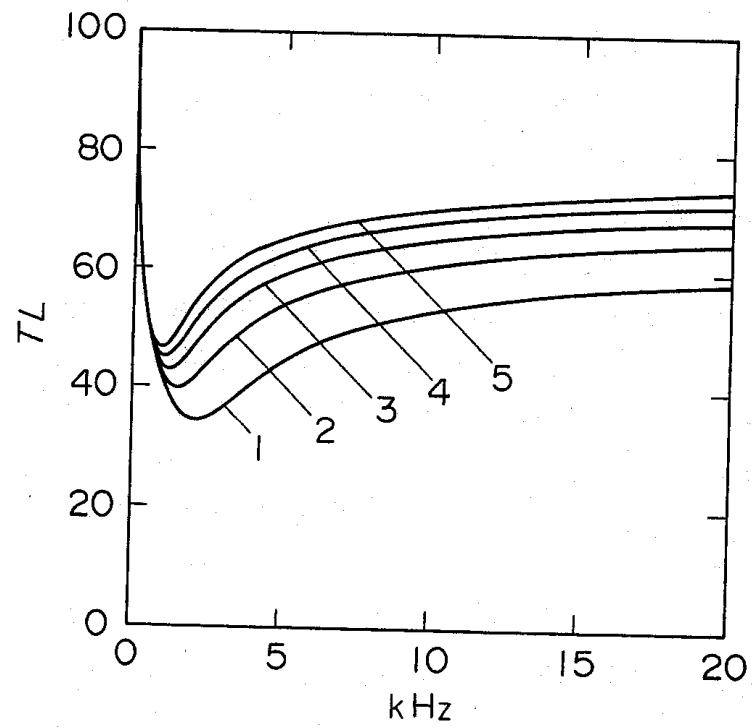

$R_{0}=0.15 \mathrm{~m}, h_{f}=0.001 \mathrm{~m}, E_{0, r}=1.7 \times 10^{10} \mathrm{~N} / \mathrm{m}^{2}$

$E_{x f}=3.4 \times 10^{10} \mathrm{~N} / \mathrm{m}^{2}, E_{\nu f}=5.1 \times 10^{9} \mathrm{~N} / \mathrm{m}^{2}$ $G_{x c}=8.3 \times 10^{8} \mathrm{~N} / \mathrm{m}^{2}, \rho_{f}=1.7 \times 10^{3} \mathrm{~kg} / \mathrm{m}^{3}$ $\rho_{c}=0.13 \times 10^{3} \mathrm{~kg} / \mathrm{m}^{3}, P_{x}=0 \mathrm{~N} / \mathrm{m}$

曲線 $1 h_{c}=0.005 \mathrm{~m}$, 曲線 $2 h_{c}=0.010 \mathrm{~m}$, 曲線 $3 h_{c}=0.015 \mathrm{~m}$

曲線 $4 h_{c}=0.020 \mathrm{~m}$, 曲線 $5 h_{c}=0.025 \mathrm{~m}$

図 $9 h_{c}$ の変化による $T L$ の変化 


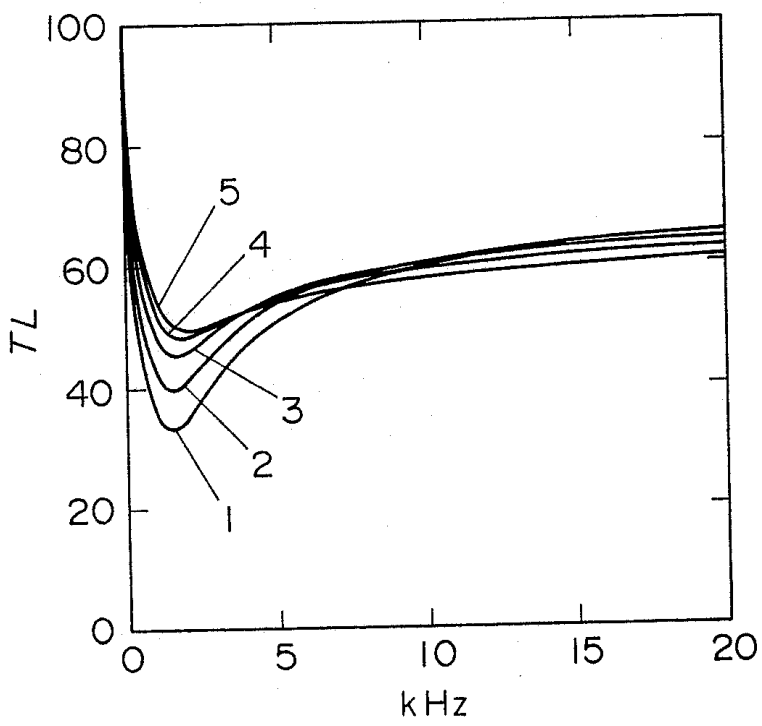

$R_{0}=0.15 \mathrm{~m}, h_{c}+h_{f}=0.011 \mathrm{~m}, E_{\theta f}=1.7 \times 10^{10} \mathrm{~N} / \mathrm{m}^{2}$

$E_{x f}=3.4 \times 10^{10} \mathrm{~N} / \mathrm{m}^{2}, E_{\nu f}=5.1 \times 10^{9} \mathrm{~N} / \mathrm{m}^{2}$ $G_{x c}=8.3 \times 10^{\mathrm{B}} \mathrm{N} / \mathrm{m}^{2}, \rho_{f}=1.7 \times 10^{3} \mathrm{~kg} / \mathrm{m}^{3}$ $\rho_{c}=0.13 \times 10^{3} \mathrm{~kg} / \mathrm{m}^{3}, P_{x}=0 \mathrm{~N} / \mathrm{m}$

曲線 $1 h_{f}=0.0005 \mathrm{~m}$, 曲線 $2 h_{f}=0.0010 \mathrm{~m}$

曲線 $3 h_{f}=0.0020 \mathrm{~m}$, 曲線 $4 \quad h_{f}=0.0030 \mathrm{~m}$

曲線 $5 h_{f}=0.0040 \mathrm{~m}$

図 10 表層とコアの厚さ配分変化による TLの変化

（5）殼の平均半径の減少とともに透過損失は全振 動数域で増大する.

（6）表層の厚さの増加は低振動数域の透過損失の 值を増大させる。

（7）コアの厚さの増加は全振動数域で透過損失の 值を増大させる.

（8）殼の厚さが固定されている場合, 表層の厚さ の増加は低振動数域の透過損失の值を増大させるが, 中高振動数域の損失の值を多少減少させる.

殼の設計に際しては種々の制約条件が考えられるた め,ここでは殻に制約条件がないものとして一般的に 得られる結果を示してある。殻にある制約条件が果せ られた場合は，その制約条件に抵触する条項を上記の 結果より外し，残りの条項を満たすべく殻を設計する ことになる，例えば殼の寸法（殼厚・平均半径）なら びに表層材の材質・寸法がともに規定されている場合 は条項 (2)，(3)ならびに(5)〜（8)は除外される. したがって遮音特性改善のためには表層材の強化方向 を殼の軸方向に合わせ，かつせん断こわさの大きい八 ニカムコアを既存の製品 ${ }^{(11)} よ り$ 選択し殼を設計する

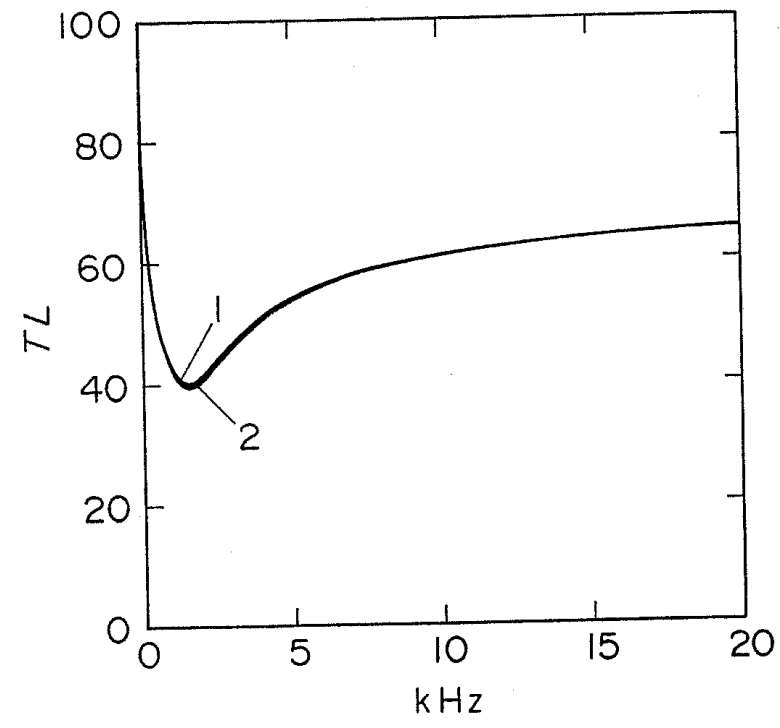

$R_{0}=0.15 \mathrm{~m}, h_{f}=0.001 \mathrm{~m}, h_{c}=0.01 \mathrm{~m}$ $E_{o f}=1.7 \times 10^{10} \mathrm{~N} / \mathrm{m}^{2}, E_{x j}=3.4 \times 10^{10} \mathrm{~N} / \mathrm{m}^{2}$ $E_{\nu f}=5.1 \times 10^{9} \mathrm{~N} / \mathrm{m}^{2}, G_{x c}=8.3 \times 10^{8} \mathrm{~N} / \mathrm{m}^{2}$ $\rho_{f}=1.7 \times 10^{3} \mathrm{~kg} / \mathrm{m}^{3}, \rho_{c}=0.13 \times 10^{3} \mathrm{~kg} / \mathrm{m}^{3}$ 曲線 $1 P_{x}=-5 \times 10^{4} \mathrm{~N} / \mathrm{m}$, 曲線 $2 P_{x}=5 \times 10^{4} \mathrm{~N} / \mathrm{m}$

図 11 軸力 $P_{x}$ の変化による $T L$ の変化

ことになる。あるいは殼の寸法ならびにハニカムコア の種類・寸法が規定されている場合は条項 (4)〜 ( 8) は除外される。したがってこの場合はできるだけ両方 向のヤング率の大きい表層材を選択し, かつ強化方向 を軸方向に合わせて殼を構成することになる。

\section{文献}

(1) Baker, E. H. and Herrmann, G., AIAA J., 4 (1966), 1063.

(2) Greenberg, J. B. and Stavsky, Y., Acta Mech., 36 (1980), 15.

(3) Jain, R. A., J. Sound Vib., 37 (1974), 379.

(4) Herrmann, G. and Baker, E. H., J. Appl. Mech., 34 (1967), 81.

(5) Mangrum, E. and Burns, J. J., Tranis. ASME, J. Mech. Des., 101 (1979), 322.

(6) Chonan, S., Trans. ASME, J. Appl. Mech., 52 (1985), 976.

(7) Shirakawa, K., J. Sound Vib., 83 (1982), 27.

(8) Chonan, S., J. Sound Vib., 93 (1984), 31.

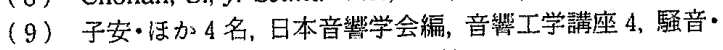
振動（上），(昭 53），5，コロナ社.

（10）北村，騒音と振動のシステム計測，（昭 54），4，コロナ社.

（11）島村・宮入，サンドイッチ構造，(昭 49）５8，日刊工業. 


\section{討論}

〔覽問〕宇治橋 貞幸・足立 忠晴 [東京工業大学工学部]

本論文を興味深く拝見した. 以下の点に関してご教 示を打願いしたい。

（1）表層材が軸方向面内力 $P_{x}$ を受けている場合, 円筒の遮音特性はどのように変化するのか.

（2）動的問題や音響問題などにおいてハニカム構 造の不均質性を考慮した場合，どのような効果が期待 できるのか.何かお考えがあ机ば，お聞かせ願いたい．

〔回答〕（1） $P_{x}$ の影響については図 11 で唡討
したが図からおわかりのように殼の遮音特性は $P_{x}$ の 大きさにほとんど影響されないということが言える。

（2）殼の構成材として比剛性 $(E / \rho)$ の大きい材料 を導入すると殼の透過損失は改善される(付 1 )。八二カ 么構造材は全体としての比剛性が大きいため，例えば 同一質量の表層材からなる単層殼に比し透過損失は大 きくなると予想される。

（付 1） 長南、機論, 54-497, C(昭 63)，175. 